\title{
Trade-economic cooperation of Ukraine and China within COVID-19 Pandemic and in post- pandemic time
}

\author{
Olha Yatsenko ${ }^{1, *}$, Tetiana Tsygankova ${ }^{1}$, Iryna Horbachova ${ }^{2}$, Oksana Aksyonova ${ }^{3}$, and \\ Valeriia Osadchuk ${ }^{4}$ \\ ${ }^{1}$ Kyiv National Economic University named after Vadym Hetman, Department of International Trade \\ and Marketing, 54/1 Peremohy Avenue, Kyiv, Ukraine, 03057 \\ ${ }^{2}$ Polissia National University, Department of International Economic Relations and European \\ Integration, 7 Staryi Boulevard, Zhytomyr, Ukraine, 10002 \\ ${ }^{3}$ Zhytomyr Institute IAPM, Department of management and administration department, 26 Peremohy \\ Street, Zhytomyr, Ukraine, 10002 \\ ${ }^{4}$ Kyiv National Economic University named after Vadym Hetman, Institute for Contemporary China \\ Studies named after Borys Kurts, 54/1 Peremohy Avenue, Kyiv, Ukraine, 03057
}

\begin{abstract}
Modern trends of trade-economic relations of the countries within the COVID-19 pandemic have been systemized in the development of mutual relations in particular economy sectors have been identified. Direct connection between the increase of export volume to China and Ukraine GDP growth has been established in the study based on the correlation-regression analysis. Weaknesses and strengths as well as opportunities and threats of mutual relations within the pandemic have been defined. The influence of the world crisis, creating a free trade area, and other factors on foreign trade circulation between Ukraine and China have been studied with the tools of empirical gravity model of international trade. Foreign trade circulation up until 2022 with and without creating a Free Trade Area has been forecast based on the modelled data. Perspective directions of trade-economic relations have been defined; the strategy of extending the trade-economic integration of Ukraine and China within the COVID-19 pandemic and in post-pandemic time within customs tariffs liberalization, intensification of symmetric interdependence and complementarity between the countries, within creating a free trade area, diversifying trade turnovers, overcoming the pandemic, reduction of crisis consequences, and strengthening cooperation in new industries of post-pandemic time has been grounded.
\end{abstract}

\section{Introduction}

Modern global economic system is characterized with tendencies of extending tradeeconomic integration of countries, strengthening their interdependence in order to reach stable economic growth of each one of them, which consequently creates challenges that

\footnotetext{
*Corresponding author: yacenkoolgakneu@gmail.com
} 
reveal both drawbacks and new opportunities, and directions of development. Over the last years, People's Republic of China has occupied the leading role of a trade partner of Ukraine [1,2]. However, the events of 2020 have had a negative effect on the system of international economic cooperation including Ukraine and China relations. Within the context, the study of the dynamics of trade-economic relations between Ukraine and China within the COVID-19 pandemic and in post-pandemic time is of interest.

Chinese economy is the first economy in the world in terms of value added and it concentrates considerable investments, innovations, scientific and technical potential. Ukraine is considering China as a strategic partner. In its turn, PRC demonstrates interest in cooperation with Ukrainian partners despite a number of negative social-economic factors. In 1992, the agreement between the Government of Ukraine and the Government of People's Republic of China established the most favored-nation treatment concerning the countries joining the World Trade Organization. Currently, legal treaty base of mutual relations numbers 300 documents.

\section{Empirical results and discussion}

Over the last years, China has occupied the leading place among trade-economic partners of Ukraine. In 2015, People's Republic of China had the second place after the Russian Federation whose index was twice as great $-12.66 \%$ - in the export structure. However, it must be mentioned that in 2019 China occupied the leading position and its market significance increased to $7 \%$ whereas the one of Russia plummeted from $12 \%$ to $6 \%$ during the years under study. The same tendency is observed in the import structure [3- 5].

According to the information from State Statistics Service of Ukraine, trade turnover with China made $\$ 12$ billion 797.9 million in 2019 and grew by $30 \%$ compared to the previous year. Commodity structure of Ukrainian export in 2019 confirms the prevailing of goods with low value added.

The part of agricultural goods and foods increased in Ukrainian export to China over the years under study. It must be mentioned that according to the information of International Trade Center, Ukrainian exporters covered $66 \%$ of Chinese joint import of corn and $64 \%$ of sunflower oil in 2019 (Table 1) [6,7].

Table 1. Key commodity items of trade between Ukraine and China in 2019, \%.

\begin{tabular}{|c|c|c|c|c|c|}
\hline \multirow[b]{2}{*}{ Export to PRC } & \multicolumn{2}{|c|}{ part* of commodities in } & \multirow[b]{2}{*}{ Import from PRC } & \multicolumn{2}{|c|}{ part* of commodities in } \\
\hline & $\begin{array}{c}\text { Export of } \\
\text { Ukraine }\end{array}$ & $\begin{array}{l}\text { Import of } \\
\text { PRC }\end{array}$ & & $\begin{array}{l}\text { Export of } \\
\text { PRC }\end{array}$ & $\begin{array}{l}\text { Import of } \\
\text { Ukraine }\end{array}$ \\
\hline Ironstone & 34 & 1.1 & Semi-conductors & 3.5 & 93 \\
\hline Corn & 13 & 66 & Smartphones & 0.2 & 57 \\
\hline $\begin{array}{l}\text { Sunflower oil } \\
\text { and seeds }\end{array}$ & 14 & 64 & Computers & 0.3 & 67 \\
\hline Rape oil & 62 & 6 & $\begin{array}{l}\text { Electric } \\
\text { transformers }\end{array}$ & 0.7 & 53 \\
\hline Barley & 21 & 10 & $\begin{array}{l}\text { Epoxy resins in } \\
\text { primary forms }\end{array}$ & 1.6 & 39 \\
\hline
\end{tabular}

In order to define the significance of PRC as a trade partner of Ukraine, we consider it reasonable to study the dependence of GDP change from the change of Ukrainian goods export to China using correlation-regressive analysis with the following input data received from statistics reports of State Statistics Service of Ukraine and International Trade Center (Table 2) $[6,7]$. 
Table 2. Initial data of export to China and GDP of Ukraine for correlation-regressive analysis of 2002-2019, \$ millions.

\begin{tabular}{|l|l|l|l|l|l|l|}
\hline Year & $\mathbf{2 0 0 2}$ & $\mathbf{2 0 0 3}$ & $\mathbf{2 0 0 4}$ & $\mathbf{2 0 0 5}$ & $\mathbf{2 0 0 6}$ & $\mathbf{2 0 0 7}$ \\
\hline GDP & 42,393 & 50,133 & 64,883 & 86,142 & 107,753 & 142,719 \\
\hline Export & 699.9 & $1,003.2$ & 831.4 & 735.2 & 569.5 & 470.0 \\
\hline Year & $\mathbf{2 0 0 8}$ & $\mathbf{2 0 0 9}$ & $\mathbf{2 0 1 0}$ & $\mathbf{2 0 1 1}$ & $\mathbf{2 0 1 2}$ & $\mathbf{2 0 1 3}$ \\
\hline GDP & 179,992 & 117,228 & 136,419 & 163,160 & 175,781 & 183,310 \\
\hline Export & 611.2 & $1,509.0$ & $1,390.4$ & $2,255.2$ & $1,858.4$ & $2,803.0$ \\
\hline Year & $\mathbf{2 0 1 4}$ & $\mathbf{2 0 1 5}$ & $\mathbf{2 0 1 6}$ & $\mathbf{2 0 1 7}$ & $\mathbf{2 0 1 8}$ & $\mathbf{2 0 1 9}$ \\
\hline GDP & 131,805 & 90,615 & 93,270 & 112,190 & 130,902 & 153,781 \\
\hline Export & $2,719.5$ & $2,439.7$ & $1,892.6$ & $2,129.0$ & $2,200.1$ & $3,590.0$ \\
\hline
\end{tabular}

The calculated correlation coefficient (r) equals to 0.409663472167864 . The received number is over 0 which proves the direct connection meaning that the increase of export volumes to China leads to the increase of Ukrainian GDP. The correlation coefficient is between 0.3 and 0.5 , which lets us draw a conclusion of connection moderation, and it is explained by the fact that Asian direction of trade partnership still finds itself on an initial stage of development.

Regressive equation will look like the following: $y=19.196 x+88456$ and if export volume is $x$ and GDP is $y$ (Fig. 1), it may demonstrate how GDP volume will change with the increase of Ukrainian export to China by $\$ 1$ million.

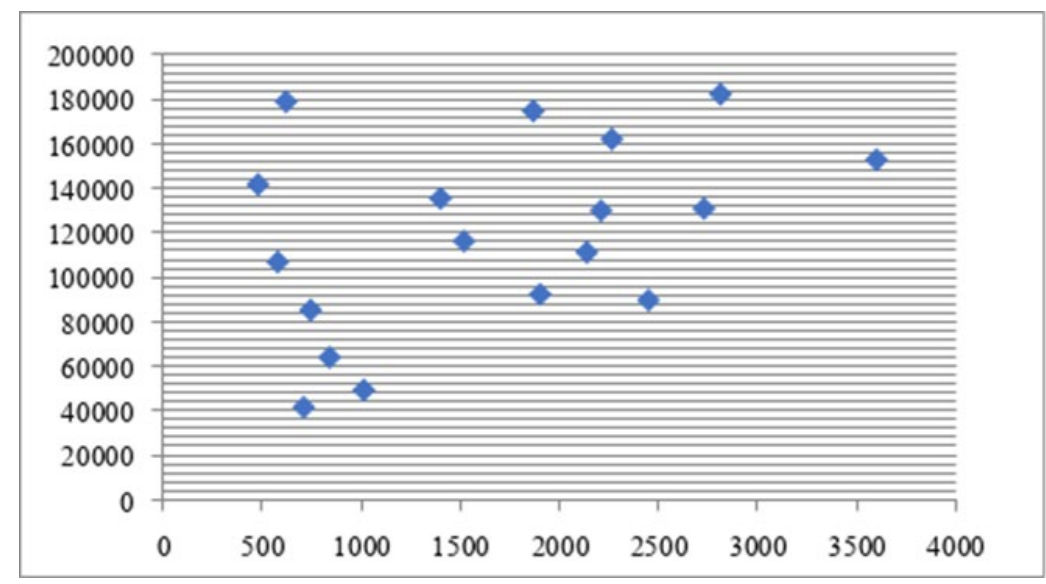

Fig. 1. Regressive equation and determination coefficient of export to PRC and GDP of Ukraine in 2019.

Coronavirus pandemic in 2020 slightly changed the dynamics of Ukrainian trade with China due to logistics complications and considerable time and resource costs for companies to get customs clearance for their goods [8-11]. However, both countries continue developing trade-economic cooperation even in such complicated conditions. An important aspect of their cooperation with the virus being spread is mutual help to combat it [12-16]. People's Republic of China keeps the leading position in international trade and is the second economy despite crisis phenomena of today [17-23].

According to the research of the American Centre of Economics and Business Research (CEBR), China may deprive the USA of its leadership five years earlier than expected - in 2028 - with one of the major reasons being the velocity of restoration from the pandemic consequences $[24,25]$. 
In order to strengthen the position on the world economic and political arena, China is initiating a number of large-scale programs and projects that deepen intercountry partnership (One Belt One Road) [26]. Having signed the Action Plan within the initiative, the Ukrainian side has multiplied economic and investment interests of China $[5,15]$. The priorities of strategic Ukrainian-Chinese partnership may be investment projects in agriculture, power engineering, infrastructure, development of high technologies within Industry 4.0, military-industrial complex, tourism, and shipbuilding [1, 4, 9, 26, 27].

Ukraine taking part in One Belt One Road initiative, whose main aim is to provide uninterrupted trade, has made one of significant steps to build a platform for strengthening trade-economic partnership with China and other participants of the project. Therefore, there has appeared an issue of creating a free trade area (FTA) with China for countries within the project.

Creating an FTA between Ukraine and PRC will meet the strategic aims of development of the two countries and will strengthen their trade-economic ties [7, 17, 22]. However, at the same time, trade development between them causes challenges for domestic economy considering the fact that over a half of negative balance of goods in Ukraine is created due to China [17-23].

Additionally, international economic partnership will look different after the crisis caused by coronavirus along with the trade war between the USA [28, 29, 30] and China, there are protectionist measures observed.

In order to define and understand major influencing factors on strategic development of trade-economic relations during the pandemic and in post-pandemic time between Ukraine and China, SWOT analysis has been made (Table 3).

The best-case scenario is to be expected when external opportunities and internal strengths $(\mathrm{S}+\mathrm{O})$ are combined; in order to realize it, it is recommended to choose the strategy of intensification of trade-economic integration.

Due to stronger connections with China, there will appear an opportunity of more efficient overcoming the pandemic and its consequences, and new opportunities for partnership will open in new post-pandemic time [4, 5, 8, 20, 24, 31-33]. Forecasting the worst is possible when external threats and internal weaknesses are combined $(\mathrm{W}+\mathrm{T})$. In such a case, it is proposed to extend sales markets in order to decrease the dependence from China as a trade partner.

In order to choose an optimal scenario for further cooperation, it is reasonable to use a gravity model that will help to define the degree of coronavirus crisis affecting the economies of Ukraine and China and mutual trade between them. In order to estimate the parameters of the model, statistical data of 2002-2019 has been taken [17- 19, 21- 23]. The GDP of China and the GDP of Ukraine have been chosen as $\mathrm{M}_{\mathrm{i}}$ and $\mathrm{M}_{\mathrm{j}}$ indices accordingly. For measuring the distance between the countries, various indices are suggested, such as geographic distance, delivery costs, etc. In such a case the cost of delivery is influenced by oil prices, therefore it was marked as $\mathrm{D}_{\mathrm{ij}}$ [34- 36].

The equation of gravity model of Tinbergen describes the dynamics of foreign trade turnover of China and Ukraine in 2002-2019 and looks like the following:

$$
\ln \left(F_{i j}\right)=-8.713+0,617 \ln \left(M_{i}\right)+0.592 \ln \left(M_{j}\right)-0.174 \ln \left(D_{i j}\right)-0.100 D V M M Y_{i j} .
$$

The carried out regression analysis has proved the hypothesis: growing GDP of the countries positively effects the foreign trade turnover between them whereas rising oil prices affect them negatively. With the use of F-test the model appeared to be statistically significant. 
Table 3. SWOT analysis of trade-economic partnership between Ukraine and China.

\begin{tabular}{|c|c|c|}
\hline INTERNAL FACTORS & $\begin{array}{l}\text { Opportunities (O) } \\
\text { 1. Partnership extension among } \\
\text { countries within One Belt One } \\
\text { Road project in ecological, trade, } \\
\text { and investment spheres and } \\
\text { implementing technologies } \\
\text { within Industry 4.0. } \\
\text { 2. Creating an FTA between } \\
\text { Ukraine and China. } \\
\text { 3. Entering the Chinese market } \\
\text { and extending trade-economic } \\
\text { partnership in priority industries. } \\
\text { 4. Using the experience of } \\
\text { overcoming COVID-19 and } \\
\text { crisis phenomena provoked by } \\
\text { the latter. }\end{array}$ & $\begin{array}{l}\text { Threats (T) } \\
\text { 1. Technological asymmetry in the } \\
\text { countries' trade: export of raw } \\
\text { material from Ukraine and high } \\
\text { technology export of PRC. } \\
\text { 2. Limited entering the Chinese } \\
\text { market by domestic business. } \\
\text { 3. Keeping the negative balance } \\
\text { in trade with China. } \\
\text { 4. High level of tariff protection } \\
\text { particularly for agricultural } \\
\text { produce. } \\
\text { 5. Conflict aggravation with the } \\
\text { USA. The possibility of a conflict } \\
\text { breakout with other countries. } \\
\text { 6. Deterioration of } \\
\text { epidemiological situation. }\end{array}$ \\
\hline $\begin{array}{l}\text { Strengths (S) } \\
\text { 1. Advantageous } \\
\text { geographical position, close } \\
\text { proximity to Europe. } \\
\text { 2. Ukraine is rich with } \\
\text { natural resources. } \\
\text { 3. High level of human } \\
\text { development and social } \\
\text { progress. } \\
\text { 4. Scientific and technical } \\
\text { potential. } \\
\text { 5. Capacious financial, } \\
\text { goods and services, } \\
\text { investment, technological } \\
\text { and other markets. } \\
\text { 6. Considerable raw } \\
\text { material base. }\end{array}$ & \begin{tabular}{|l}
\multicolumn{2}{|c|}{ Expectations $(\mathbf{S}+\mathbf{O})$ : } \\
Liberalization of trade, \\
strengthening trade-economic \\
relations, intensification of \\
symmetric interdependence \\
between both countries, creating a \\
free trade area, economic growth, \\
diversification of trade torrents, \\
overcoming the pandemic and \\
decreasing crisis consequences, \\
strengthening partnership in new \\
industries in post-pandemic time. \\
Strategy: \\
INTENSIFICATION OF \\
TRADE-ECONOMIC \\
INTEGRATION
\end{tabular} & $\begin{array}{l}\text { Expectations (S+T): } \\
\text { Growing demand for import goods } \\
\text { on the domestic market, decrease of } \\
\text { product range of national export. } \\
\text { Growing disproportion in } \\
\text { producing and technological } \\
\text { opportunities of countries, growing } \\
\text { dependence upon export in raw } \\
\text { material sector, low level of goods } \\
\text { and geographic diversification of } \\
\text { Ukrainian export. } \\
\text { Strategy: } \\
\text { POLICY OF INNOVATIVE } \\
\text { BREAKTHROUGH }\end{array}$ \\
\hline $\begin{array}{l}\text { Weaknesses (W) } \\
\text { 1. Military conflict in the } \\
\text { East of Ukraine. } \\
\text { 2. Social, political, and } \\
\text { economic instability. } \\
\text { 3. Power dependence of the } \\
\text { country. } \\
\text { 4. Low competitiveness of } \\
\text { domestic goods and services. } \\
\text { 5. Instability of national } \\
\text { currency rate. } \\
\text { 6. Complicated } \\
\text { epidemiologic situation. }\end{array}$ & 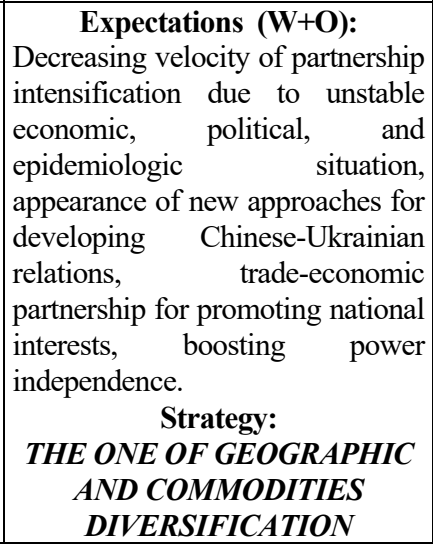 & $\begin{array}{l}\text { Expectations (W+T): } \\
\text { Decreasing trade turnover between } \\
\text { the countries, destabilizing trade- } \\
\text { economic relations of the two } \\
\text { countries, takeover of Ukrainian } \\
\text { companies, weakening } \\
\text { competitiveness of Ukrainian } \\
\text { companies, aggravating investment } \\
\text { climate in Ukraine, appearance of } \\
\text { new trade limitations and obstacles. } \\
\text { Strategy: } \\
\text { STRUCTURE DIVERSION OF } \\
\text { FOREIGN TRADE }\end{array}$ \\
\hline
\end{tabular}

Apart from the current state of trade between the two countries under scrutiny, the gravity model also allows us to define the volume of mutual trade for the following years. In order to do so, we used forecast indices of the International Monetary Fund concerning GDP of Ukraine and China, and oil prices in 2020-2022 [19]. 
According to the results of studying the gravity model and the forecast of experts, the foreign trade turnover in 2022 is expected to increase to $\$ 11,740.2$ mill (Fig. 2).

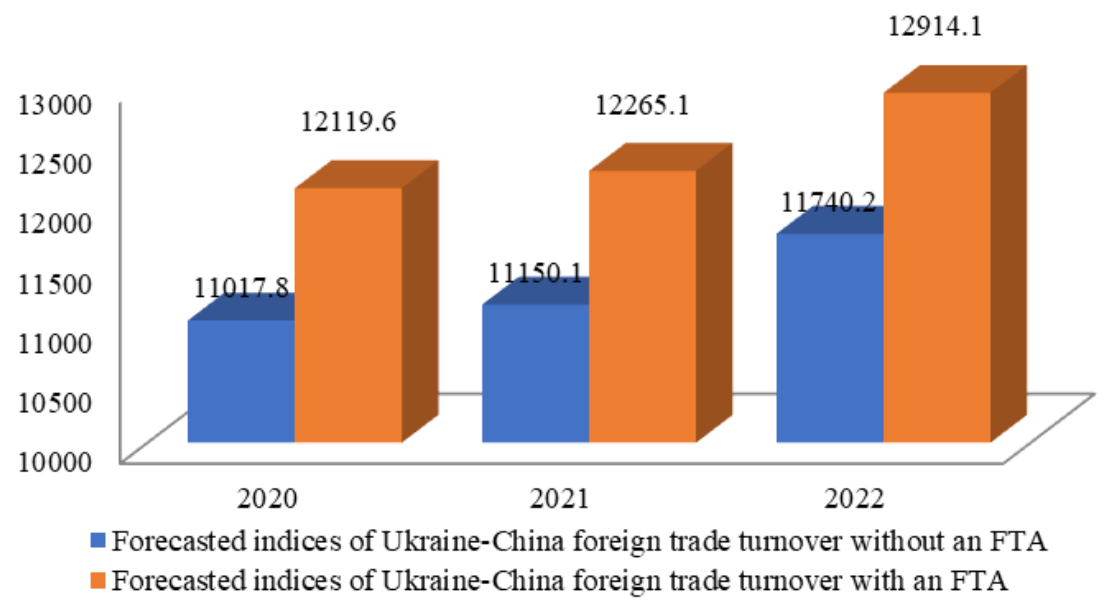

Fig. 2. Forecasted trade turnover between Ukraine and China in 2020-2022, \$ millions.

For visual representation, the foreign trade turnover between Ukraine and China in 2002-2019 has been modelled (Fig. 3) [18, 21-23].

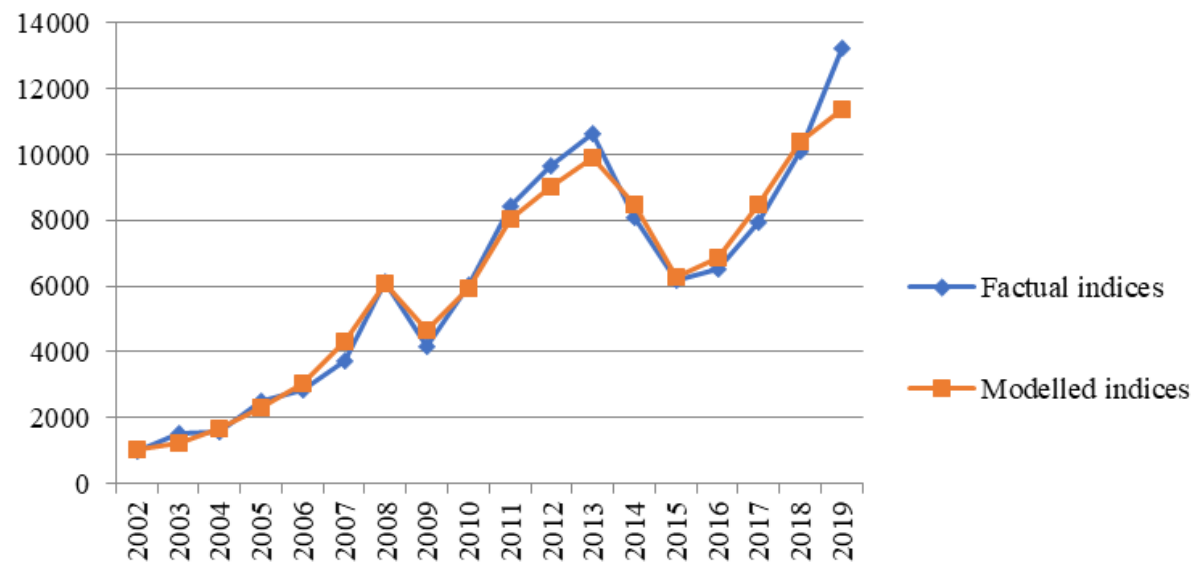

Fig. 3. Factual and modelled indices of foreign trade turnover between Ukraine and China in 20022019, \$ millions.

Creating an FTA and intensifying partnership may favorably influence the change of the forecasted indices, in particular, mutual trade turnover will increase by $\$ 0.1$ for every dollar as a result of an active free trade area.

This model also allows us to draw a conclusion that should the gross domestic product of China increase by $\$ 1$, the foreign trade turnover of the countries will increase by $\$ 0.617$; should the GDP of Ukraine increase by $\$ 1$, the foreign trade turnover will increase by $\$ 0.592$; should oil prices increase by $\$ 1$, the foreign trade turnover between the two countries will increase by $\$ 0.174$. 
The carried out analysis confirms that integration intensification is reasonable [34, 3740]. However, trade policy of Ukraine had been inefficient before the crisis and therefore now it needs rapid renovation. The aspiration of the country to join the European Union and the desire of China to increase its market share in the EU confirms the necessity of further harmonization of the legislation of both countries with the European one [32, 37-40]. In the modern trade policy of the EU, major quality features are transparency and efficiency. However, in new conditions caused by the coronavirus pandemic, its constant renovation is necessary which primarily concerns the following:

- global chains of forming value, creative, and digital economy;

- intensification of mobility of experts, managers and service suppliers;

- extending cooperation and partner relations with countries interested in investment and trade relations issues;

- creating favorable conditions for development of small and medium business.

The fact that regulatory issues that evolve within cooperation of China and the EU may directly concern domestic procedures, rules and requirements, must be taken into consideration. Should Chinese standards rise to the European ones, adapted Ukrainian export will not encounter difficulties or obstacles. On the other hand, should China provide alleviation, the process of domestic producer entering its market will be simplified.

Additionally, when cooperating with PRC that, in its turn, rapidly adjusts to world tendencies and sometimes even founds them, there appears an opportunity to adopt Chinese experience of conducting trade policy that is realized through tariff and non-tariff tools. Customs tariff of China consists of MFN rates, general tariff rates, tariff quota rates, contract tariff rates, special preferential tariff, and temporary duties. Over the last 20 years, tariff protection of China has been decreasing. According to the WTO data, average customs duty in China in 2019 was equal to $10.0 \%, 5.9 \%$ for agricultural goods, and $6.6 \%$ for non-agricultural goods. In Ukraine, arithmetical mean rate of the end bound tariff in 2019 was equal to $5.8 \%, 34 \%$ for agricultural produce, and $12.2 \%$ for non-agricultural goods [18].

A considerable barrier for Ukrainian export to enter the market of China is non-tariff measures, too, whose larger number concerns technical, sanitary, and phytosanitary regulation and licensing a significant part of import. Moreover, requirements to import may change rapidly and differ depending on ports and regions whose regulation is complicated and non-transparent.

China will primarily benefit from establishing an FTA. First and foremost, it is caused by subjective and objective factors; moreover, rates of Ukrainian customs tariffs are bound which testifies invariability and stability of entered obligations and their reliability. Therefore, a decision of forming an FTA must be weighed and signed within mutually beneficial and transparent cooperation.

In order to promote trade-economic interests of Ukrainian business on the Chinese market, representatives of economic diplomacy of Ukraine must use a number of work methods aimed at protecting economic interests of domestic producer on the Chinese market, particularly: boosting overcoming and removal of tariff and non-tariff barriers; analyzing mutual trade-economic relations as well as the ones among the third parties with host country; searching potentially possible free niches and favorable conditions for realizing produce of domestic producer; monitoring markets and industries that are a priority for the Ukrainian side: machinery construction, agriculture, food and light industries, power engineering, etc.; establishing business contacts with Chinese representatives of different economy sectors, and meeting and negotiating with potential partners; collecting and spreading the information about trade-economic activity of Ukraine and perspectives of its extension, and others. 


\section{Conclusions}

Modern international economy system is characterized with interdependance of countires that generates both challenges and new development opportunities. The crysis caused by coronavirus has changed the tendency of integration processes having intensified the use of protectionist measures. The policy of deliberate economic slowing down and the policy of minimizing economic damage with cooperation intensification have become features of trade and investment processes and transformation of approaches of opposing the pandemic. The influence of the pandemic consequences on international economic relations of countries is demonstrated through unilateralism, protectionism, increasing uncertainty factors, dynamisation of trade arguments, decreasing economic indices, reduction in import demand, and discontent of population.

The dynamics of trade-economic cooperation between Ukraine and China has also undergone some changes. Mutual relations of the countries are now defined as a strategic parnership. Over the last years, China has occupied a leading position among tradeeconomic partners of Ukraine. Modern export and import structures affirm a disproportion that is dangeruos for Ukraine: export of raw material from Ukraine and high-technology import from PRC; keeping negative balance of foreign trade with the world and with China in particular; weak commodities and geographic diversification of Ukrainian export. Direct moderate dependance between the change of GDP of Ukraine and export to China has been established using correaltion-regression analysis, which indicates the importance of the cooperation direction under study.

PRC is implementing a number of projects with One Way One Belt project being one of the most important for Ukraine since participating in it increases economic and investment interest of China towards the Ukrainian side. The following areas are defined as priority directions of cooperation and attraction of Chinese investment: agriculture, power engeneering, infrustructure, tourism, military-industrial complex, shipbuilding, technology within Industry 4.0. In order to strenghten cooperation and positions of Ukraine as a link in trade torrents between China and the EU, the issue of creating a Ukrainian-Chinese free trade area is being considered, which may create a number of threats apart from opportunities within mutual partnership in its turn.

Possible scenarios of further trade-economic cooperation between Ukraine and China have been identified and substantiated, and their extention has been reasoned. It has been defined that the most optimal variant is extension of mutual cooperation between Ukraine and China with the dysproportion of their development, keeping the rules and norms of international trade system when considering today's realia.

Using gravity model of international trade, hypothetical effects from possible creating a free trade area, coronavirus crysis and other factors on foreign trade turnover (FTT) between Ukraine and China have been established, their volume has been forecasted for the following years with and without an FTA (free trade area) being created. In particular, it has been defined that mutual trade turnover of the countries will increase by $\$ 0.1$ for every dollar as a result of a free trade area being created; should GDP of China increase by $\$ 1$, foreign trade turnover of the countries will increase by $\$ 0.617$; should GDP of Ukraine increase by $\$ 1$, FTT will increase by $\$ 0.592$; should oil prices increase by $\$ 1$, FTT between the two countries will increase by $\$ 0.174$. Also, using the regressive analysis, the hypothesis stating that an increase of GDP of the partnering countries positively influences FTT between them while an increase of oil prices effects it negatively has been proved.

"Windows of opportunity" in development of mutual trade-economic relations in the following areas have been identified: infrastructure, logistics (modernization of rail ways and ports, building modern roads), agriculture and food industry (attracting Chinese investment into process manufacturing for redirecting from raw material export to highly 
marginal ready-made produce), power engineering, military-industrial complex (modernization of facilities), digitalization of business processes and transition to Industry 4.0.

Recommendations for boosting trade-economic cooperation within COVID-19 pandemic and in post-pandemic time have been substantiated, particularly: active participation in One Way One Belt initiative (extending harmonization of legislation of Ukraine with Chinese and European ones); digitalization and intellectualization of international trade activities (attracting Chinese investment into development of Industry 4.0. technologies); diversification of goods structure of export and monitoring priority market sides: machinery construction, agriculture, food and light industries, power engineering; supporting domestic producer (collecting and spreading information; insuring against risks of foreign trade agreements realizing).

\section{References}

1. Ma, B., \& Soroka, L. (2020). The Cooperation between China and Ukraine in Space Exploration: Genesis and Development. Advanced Space Law, 5, 58-70. https://doi.org/10.29202/asl/2020/5/6

2. Oleshchuk, P. (2020). Political Franchising as a Modern Political Technology. Ukrainian Policymaker, 7, 35-42. https://doi.org/10.29202/up/7/5

3. Raišienè, A. G., Yatsenko, O., Nitsenko, V., Karasova, N., \& Vojtovicova, A. (2019). Global dominants of Chinese trade policy development: Opportunities and threats for cooperation with Ukraine. Journal of International Studies, 12(1), 193-207. https://doi.org/10.14254/2071-8330.2019/12-1/13

4. Svyrydenko, D., \& Stovpets, O. (2020). Chinese Perspectives in the "Space Race" through the Prism of Global Scientific and Technological Leadership. Philosophy and Cosmology, 25, 57-68. https://doi.org/10.29202/phil-cosm/25/5

5. Yatsenko, O. (2019). Trade and economic cooperation between ukraine and china: $\begin{array}{llll}\text { opportunities and threats. } & \text { 5KRAINE-CHINA, }\end{array}$ https://sinologist.com.ua/wp-content/uploads/2019/05/N15 2019.pdf

6. State Customs Service of Ukraine (2020). https://bi.customs.gov.ua/trade/\#/imex

7. International Trade Center (2019). Trade Map. https://www.trademap.org/

8. Yatsenko, O. (2017). Trade policy as an instrument of economic development. The international scientific and analytical, reviewed, printing and electronic journal of Paata Gugushvili Institute of Economics of Ivane Javakhishvili Tbilisi State University «Ekonomisti», (2), 55-71.

9. Kalyuzhna, N., Khodzhaian, A., \& Baron, I. (2021). Identification of globalization threats to the economic sovereignty of countries with transition economies. Naukovyi Visnyk Natsionalnoho Hirnychoho Universytetu, 1, 154-164. https://doi.org/10.33271/nvngu/2021-1/154

10. Nitsenko, V., Chukurna, O., Mardani, A., Streimikis, J., Gerasymchuk, N., Golubkova, I., \& Levinska, T. (2019). Pricing in the Concept of Cognitive Marketing in the Context of Globalization: Theoretical, Methodological and Applied Aspects. Montenegrin Journal of Economics, 15(4), 131-147. https://doi.org/10.14254/1800$\underline{5845 / 2019.15-4.10}$

11. Flissak, K. (2013). Formy ta metody ekonomichnoi dyplomatii u sferi torhovelnoekonomichnoho ta investytsiinoho spivrobitnytstva. Ekonomichnyi analiz, (12), 306310. 
12. Yankovyi, O., Goncharov, Y., Koval, V., \& Lositska, T. (2019). Optimization of the capital-labor ratio on the basis of production functions in the economic model of production. Naukovyi Visnyk Natsionalnoho Hirnychoho Universytetu, 4, 134-140. https://doi.org/10.29202/nvngu/2019-4/18

13. Kucher, A., Mendrukh, Y., Khodakevich, O., \& Dybkova, L. (2019). Management of formation of communicative competence of the future economists: case study of Ukraine. TEM Journal, 8(4), 1127-1136. https://doi.org/10.18421/TEM84-04

14. Andriushchenko, K., Tepliuk, M., Boniar, S., Ushenko, N., \& Liezina, A. (2019). Influence of cost drivers on value-oriented management of investment activity of companies. Investment Management and Financial Innovations, 9(1), 353-364. https://doi.org/10.21511/imfi.16(3).2019.31

15. Danyliuk, V., Riepina, I., Shafalyuk, O., Kovylina, M., \& Nitsenko, V. (2020). Functional and investment strategies of technical development of enterprises. Naukovyi Visnyk Natsionalnoho Hirnychoho Universytetu, 3, 115-121. https://doi.org/10.33271/nvngu/2020-3/115

16. Koval, V., Mikhno, I., Trokhymets, O., Kustrich, L., \& Vdovenko, N. (2020). Modeling the interaction between environment and the economy considering the impact on ecosystem. E3S Web Conferences, 166, 13002. https://doi.org/10.1051/e3sconf/202016613002

17. Embassy of Ukraine in the People's Republic of China (n.d.). https://china.mfa.gov.ua

18. The World Trade Organization (2020). http://www.worldbank.org/

19. The International Monetary Fund (2020). https://www.imf.org/en/Home

20. The Observatory of Economic Complexity (2020). https://oec.world

21. State Fiscal Service of Ukraine (2020). http://sfs.gov.ua

22. National Bureau of Statistics of China (n.d.). http://www.stats.gov.cn

23. The World Bank Group (2020). http://www.worldbank.org/

24. Burden, L. (2020). China's Economy Set to Overtake U.S. Earlier Due to Covid Fallout. Bloomberg. https://www.bloomberg.com/news/articles/2020-12-26/covidfallout-means-china-to-overtake-u-s-economy-earlier?sref=Y0jVLcFo

25. Zou, C., \& Gao, W. (2019). China as a Subject of International Education: Experience of Development. Future Human Image, 11, 120-129. https://doi.org/10.29202/fhi/11/14

26. Kyianytsia, L.L. (2019). The One Belt One Road Initiative as a New Silk Road: The (Potential) Place of Ukraine. Ukrainian Policymaker, 4, 21-26. https://doi.org/10.29202/up/4/3

27. Koval, V., Duginets, G., Plekhanova, O., Antonov, A., \& Petrova, M. (2019). On the supranational and national level of global value chain management. Entrepreneurship and Sustainability Issues, 6(4), 1922-1937. http://doi.org/10.9770/jesi.2019.6.4(27)

28. Yatsenko, O., Nitsenko, V., Karasova, N., William, H.M. \& Parcell, J.L. (2017). Realization of the Potential of Ukraine - EU Free Trade Area in Agriculture. Journal of International Studies, 10(2), 258-277. https://doi.org/10.14254/2071-8330.2017/10$\underline{2 / 18}$

29. Liu, J. (2020). China Airlines "Escort" to Fight Outbreak Prevention and Control. Advanced Space Law, 5, 108-110. https://doi.org/0.29202/asl/2020/5/10

30. Piliaiev, I. (2019). The Value Dichotomy Curse of Ukraine's Modernization: to Break, or not to Be. Ukrainian Policymaker, 5, 68-76. https://doi.org/10.29202/up/5/8 
31. Dankeieva, O., Solomianiuk, N., Strashynska, L., Fiedotova, N., Soloviova, Y., \& Koval, V. (2021). Application of Cognitive Modelling for Operation Improvement of Retail Chain Management System. TEM Journal, 10(1), 358-367. https://doi.org/10.18421/TEM101-45

32. Fedotova, Y. (2019). Features of the trade policy of the countries of the European Union. Problemy systemnoho pidkhodu $\mathrm{v}$ ekonomitsi. (3), 41-46. https://doi.org/10.32782/2520-2200/2019-3-6

33. Tkachenko, O., Kulaga, I., Kozlovska, L., Shvidanenko, O., \& Busarieva, T. (2021). The impact of knowledge components on the world competitiveness. Naukovyi Visnyk Natsionalnoho Hirnychoho Universytetu, 1, 198-203. https://doi.org/10.33271/nvngu/2021-1/198

34. Yeshchuk, O., \& Vasina, A. (2019) Chinese Space Law: Problems and Areas of Reforming. Advanced Space Law, 3, 140-150. https://doi.org/10.29202/asl/2019/3/12

35. Nitsenko, V., Kotenko, S., Hanzhurenko, I., \& Ingram, K.L. (2020). Determination of Weight Coefficients for Stochastic and Fuzzy Risks for Multimodal Transportation. Journal of Physics: Conference Series, 1529, 032007. https://doi.org/10.1088/17426596/1529/3/032007

36. Kotenko, S., Nitsenko, V., Hanzhurenko, I., \& Havrysh, V. (2020). The Mathematical Modeling Stages of Combining the Carriage of Goods for Indefinite, Fuzzy and Stochastic Parameters. International Journal of Integrated Engineering, 12(7), 173-180. https://doi.org/10.30880/ijie.2020.12.07.019

37. Heldak, M., Kucher, A., Stacherzak, A., \& Kucher, L. (2018). Structural transformations in agriculture in Poland and Ukraine: towards economic sustainability. Journal of Environmental Management and Tourism, IX, 8(32), 1827-1841. https://doi.org/10.14505//jemt.v9.8(32).24

38. Ciuła, J., Gaska, K., Siedlarz, D., \& Koval, V. (2019). Management of sewage sludge energy use with the application of bi-functional bioreactor as an element of pure production in industry. E3S Web Conference, 123, 01016. https://doi.org/10.1051/e3sconf/201912301016

39. Kalinichenko, A., \& Havrysh, V. (2019). Feasibility study of biogas project development: technology maturity, feedstock, and utilization pathway. Archives of Environmental Protection, 45(1), 68-83. https://doi.org/10.24425/aep.2019.126423

40. Nguyen, T.T.T., \& Do, T.H. (2020). Vietnamese Cultural Identity in the Face of Cultural Globalization. Future Human Image, 14, 28-35. https://doi.org/10.29202/fhi/14/4 